\title{
Fat Graft Migration Causing Recurrent Cervical Cord Compression
}

\author{
Reküran Servikal Kord Kompresyonuna Neden Olan Yağ Grefti Yer \\ Değiştirmesi
}

Ritesh KANSAL, Santosh NAMA, Amit MAHORE, Nitin DANGE, Sanjay KUKREJA

Seth G.S. Medical College @ K.E.M. Hospital, Department of Neurosurgery, Mumbai, India

Correspondence address: Ritesh KANSAL / E-mail: drkansal@yahoo.co.in

\begin{abstract}
AIM: Fat graft migration following spinal cord surgery is an uncommon problem. Only few cases of fat graft migration causing cauda equine syndrome, recurrent sciatica, and root compression following lumbar spine surgery have been reported. We report a case of fat graft migration causing symptomatic cervical cord compression.

MATERIAL and METHODS: A 45-years-old male with cervical spondylosis underwent anterior C4-5 discectomy and excision of hypertrophied ligament. A dural tear that occurred during the procedure was repaired with fat graft harvested from thigh. Significant improvement in stiffness was noted postoperatively. After 15 days, the patient presented again with worsening lower limbs stiffness. Magnetic resonance imaging of spine was done which revealed displacement of the fat graft causing cervical cord compression.

RESULTS: Re-exploration was done and the migrated fat graft was removed. Post operatively patient noticed significant improvement in stiffness in both lower limbs.

CONCLUSION: Autologous fat graft is one of the best materials used in sealing the dural cerebrospinal fluid leak during spinal surgery. However sometimes it may migrate and cause compression of cord and roots with relative symptoms. This complication should be kept in mind as removal of migrated fat graft will relieve these symptoms.
\end{abstract}

KEYWORDS: Cervical spine, Discectomy, Fat graft

ÖZ

AMAÇ: Spinal kord cerrahisi sonrasında yağ grefti yer değiştirmesi sık görülmeyen bir problemdir. Lumber omurga cerrahisi sonrasında kauda ekuina sendromu, reküran siyatik ve kök kompresyonuna neden olan sadece birkaç yağ grefti yer değiştirmesi vakası bildirilmiştir. Semptomatik servikal kord kompresyonuna yol açan bir yağ grefti yer değiştirmesi vakası bildiriyoruz.

YÖNTEM ve GEREÇLER: Servikal spondilosisi olan 45 yaşında bir erkeğe hipertrofiye uğramış ligamanın eksizyonuyla anterior C4-5 diskektomi yapıldı. İşlem sırasında oluşan bir dura yırtığı üst bacaktan alınan bir yağ greftiyle tedavi edildi. Postoperatif olarak katılıkta önemli bir düzelme saptandı. 15 günden sonra hasta tekrar kötüye giden alt uzuv katılığıyla başvurdu. Omurga manyetik rezonans görüntülemesi yağ greftinin yer değiştirdiğini ve servikal kord kompresyonuna yol açtığını gösterdi.

BULGULAR: Tekrar keşif yapıldı ve yer değiştirmiş yan grefti çıkarıldı. Postoperatif olarak hasta her iki uzuvda katılıkta önemli bir düzelme fark etti.

SONUÇ: Otolog yağ grefti spinal cerrahi sırasında dural serebrospinal sıvı sızıntısını mühürlemekte kullanılan materyallerin en iyilerinden biridir. Ancak bazen yer değiştirebilir ve kord ve köklerde kompresyona ve ilgili belirtilere yol açabilir. Yer değiştirmiş yağ greftinin çıkarılması bu belirtileri giderebileceğinden bu komplikasyon akılda tutulmalıdır.

ANAHTAR SÖZCÜKLER: Servikal omurga, Diskektomi, Yağ grefti

\section{INTRODUCTION}

Cerebrospinal fluid leak during spinal surgery is relatively common. There are various materials to seal dural tube defect like autologous fat, muscle, fibrin glue, surgicel or the combination of these materials. Autologous fat graft serves as an excellent material to seal the dural tear, prevents scar formation, and do not adhere to the neural elements. The fat survives for a long time and becomes revascularized. However sometimes fat graft may migrate and cause compression of cord and roots with relative symptoms. This complication should be kept in mind since removal of migrated fat graft will relieve the symptoms.

\section{CASE REPORT}

A 45-year-old male patient presented with gradually progressive stiffness of both lower limbs since four years. There was no history of bowel or bladder involvement. On examination, the tone was increased in both lower limbs, power was grade 4 in both lower limbs and grade 5 in 
upper limbs (MRC Grading). Magnetic resonance imaging of cervical spine shows C3 to C7 hypertrophied posterior longitudinal ligament with severe cord compression at C4-5 level (Figure 1). The patient was advised surgery. An anterior cervical approach was used for C4-5 discectomy and excision of hypertrophied ligament at that level without bone graft. The posterior longitudinal ligament was adherent to the duramater. An accidental tear occurred through which cerebrospinal fluid leak was noticed during surgery. The dural defect was plugged with an autologous fat graft harvested from thigh. The patient noticed significant improvement in stiffness immediately following surgery and was discharged on fourth post operative day. He again presented to our outpatient department after fifteen days, complaining of increased stiffness in both lower limbs which was more than preoperative stiffness. Magnetic resonance imaging (MRI) of the cervical spine was obtained which revealed displacement of fat graft causing compression of cervical cord (Figure 2).
The patient was re-explored through the previous incision. Intra-operatively the fat graft was noticed to have migrated posteriorly and indenting the cervical cord. The fat graft causing the compression was removed and the cord decompressed. The dural tear caused during the previous surgery was found healed with no evidence of cerebrospinal fluid leak now. Post operative MRI cervical spine was done which showed excision of the fat graft and decompressed cord (Figure 3). Post operatively, the patient noticed significant improvement in stiffness in both lower limbs.

\section{DISCUSSION}

Cerebrospinal fluid leaks are relatively common following spinal surgeries like excision of disc, decompressive laminectomy or excision of ossified posterior longitudinal ligament. Leakage may occur during the surgery due to inadvertent dural tears or at the suture line postoperatively. A general belief is that in patients in whom a durotomy has

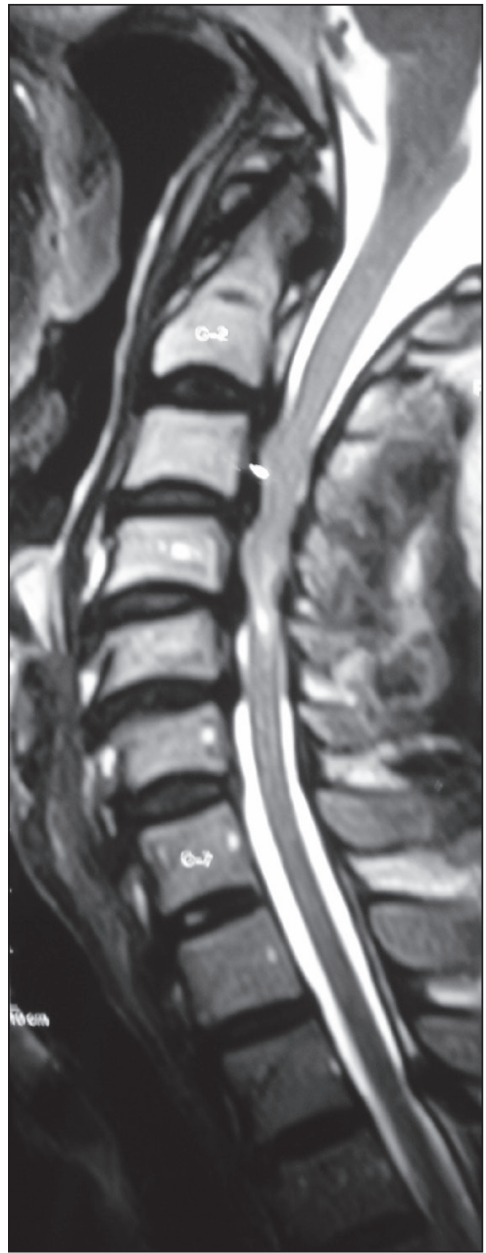

Figure 1: Pre operative T2-weighted magnetic resonance sagittal image of cervical spine showing C3 to C7 hypertrophied posterior longitudinal ligament with severe cord compression at C4-5 level.

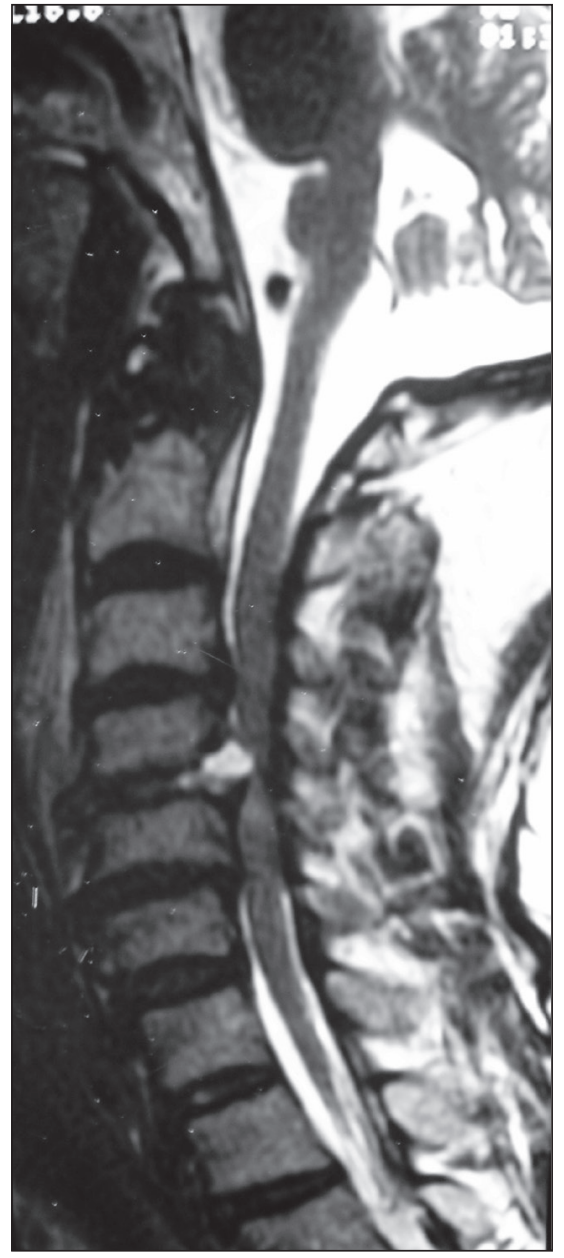

Figure 2: T2-weighted magnetic resonance sagittal image of cervical spine after first surgery showing displacement of fat graft at C4-5 level causing compression of cervical cord.

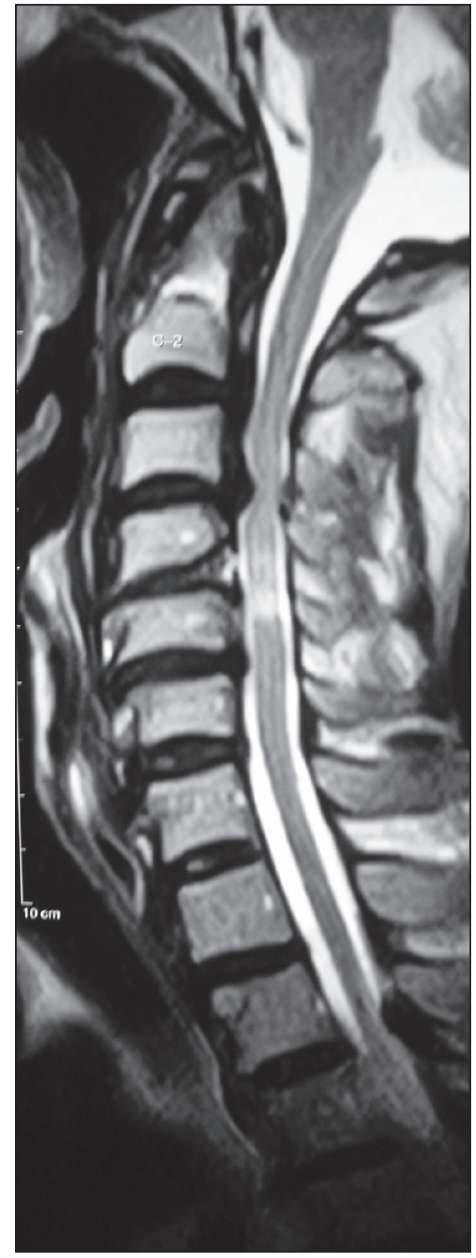

Figure 3: T2-weighted magnetic resonance sagittal image of cervical spine after second surgery showing excision of the fat graft and decompressed cord. 
occurred, complications rarely develop that require surgical intervention (8). Common complaints of these patients include postural headache, photophobia, persistent wound drainage, and pseudomeningocele formation (18). Subdural hematoma may also occur after a dural tear during spinal laminectomy (11). Cerebrospinal fluid leakage poses a risk of significant morbidity with the potential for meningitis.

Management of cerebrospinal fluid leak following surgery is complex and consists of insertion of a spinal fluid drain, as well as administration of prophylactic or therapeutic antibiotics (9). In cases of persistent CSF leakage, surgical re-exploration may become necessary. Hence cerebrospinal fluid leak should be detected during surgery and should be treated properly. Dural grafts should be used when primary closure cannot be achieved because of dural retraction and shrinkage, which can occur with the coagulation of bleeding points on the dura mater, or when the dura must be excised because of neoplastic infiltration (15).

Cerebrospinal fluid leak during spinal surgery can be managed by various techniques like sealing the dural defect using autologous fat graft, fibrin glue, muscle graft, surgicel or the combination of these materials. Interest in the repair of dural defects has increased to minimize or prevent postoperative meningospinal adhesions; thus, many synthetic materials and processed membranes have been tested. Many were abandoned because of complications, namely, excessive tissue reaction and inflammation, host tissue encapsulation and fibroses, and/or delayed hemorrhage $(1,5,7,14,17)$. An ideal dural substitute should have the following characteristics: induce as little inflammatory and/ or immunogenic response as possible; produce little or no adhesions to the underlying brain; prevent CSF leakage; and be resistant to infection, nontoxic, free of any complications, and cost effective $(10,12,16)$.

Gelfoam has been used to cover dural tears and dural suture lines, but it does not provide a water-tight seal. Furthermore, Gelfoam has been shown to cause scarring (13). In recent years, fibrin glue of various types has gained in popularity for use as a dural sealant. Experimental evidence, obtained from study of rat cerebrospinal fluid rhinorrhea model, has shown that muscle graft in combination with fibrin glue (presumably due to its adhesive sealing properties) is superior to either muscle packing alone or fibrin glue alone (2).

Autologous fat transplants serve as an excellent material to seal the dural tear, prevents scar formation, and do not adhere to the neural elements; the fat survives for a long time and becomes revascularized. Fat graft can be harvested from the site of surgery, lower part of abdomen or lateral aspect of thigh. Trevor and colleagues have studied differences in free grafts and pedicle fat grafts for dural repair. They found no benefit to using pedicle fat grafts (19). Fat graft is very handy in sealing dural tube defects during spinal surgery. However, sometimes fat graft may migrate and cause compression of cord and roots with relative symptoms. Only few cases have reported fat graft migration causing cauda equina syndrome, recurrent sciatica, and root compression following lumbar spine surgery $(3,4,6,20,21)$. Fat graft migration can also cause compression of cervical cord. Fat graft migration occurs by the action of paraspinal muscles (3). This is the first case report in which fat graft has migrated causing compression of cervical cord with relative symptoms.

Although autologous fat graft is an excellent material in sealing dural tube defect, it can rarely migrate and cause compression of cord and roots. Although the transplantation of adipose tissue has many advantages, including the prevention of postoperative epidural fibrosis, great care is needed when applying a fat graft intra-operatively. When a postoperative neurologic deficit develops, herniation of the fat graft must be considered. An emergent operation is the treatment of choice for this particular complication. Removal of migrated fat will relieve the symptoms.

\section{CONCLUSION}

Autologous fat graft is one of the best materials used in sealing the dural cerebrospinal fluid leak during spinal surgery. However sometimes it may migrate and cause compression of cord and roots with relative symptoms. This complication should be kept in mind as removal of migrated fat graft will relieve these symptoms.

\section{REFERENCES}

1. Adegbite AB, Paine KW, RozdilskyB:The role of neomembranes in formation of hematoma around Silastic dura substitute. Case report. J Neurosurg 58:295-297, 1983

2. Black P: Cerebrospinal fluid leaks following spinal surgery: Use of fat grafts for prevention and repair. Technical note. J Neurosurg 96:250-252, 2002

3. Cabezudo JM, Lopez A, Bacci F: Symptomatic root compression by a free fat transplant after hemilaminectomy. Case report. J Neurosurg 63:633-635,1985

4. Chuang TY, Chen WJ, Chen LH, Niu CC, Shih CH: Acute postoperative aggravation of radiculopathy as a complication of free fat transplantation in lumbar disc surgery: Case report. Changgeng Yi Xue Za Zhi 22:498-502,1999

5. Cohen AR, Aleksic S, Ransohoff J: Inflammatory reaction to synthetic dural substitute. Case report. J Neurosurg 70: 633-635, 1989

6. Deburge A, Bitan F, Lassale B, Vaquin G: Cauda equina syndrome caused by migration of a fat graft after laminoarthrectomy. Rev Chir Orthop Reparatrice Appar Mot 74:677-678,1988

7. Gomez H, Little JR: Spinal cord compression: A complication of silicone-coated Dacron dural grafts. Report of two cases. Neurosurgery 24:115-118, 1989

8. Jones AA, Stambough JL, Balderston RA, Rothman RH, Booth RE Jr: Long-term results of lumbar spine surgery complicated by unintended incidental durotomy. Spine 14:443-446, 1989

9. Kitchel SH, Eismont FJ, Green BA: Closed subarachnoid drainage for management of cerebrospinal fluid leakage after an operation on the spine. J Bone Joint Surg 71:984-987, 1989 
10. Lee JF, Odom GL, Tindall GT: Experimental evaluation of silicone- coated Dacron and collagen fabric-film laminate as dural substitutes. J Neurosurg 27:558-564, 1967

11. Lu CH, Ho ST, Kong SS, Cherng $\mathrm{CH}$, Wong CS: Intracranial subdural hematoma after unintended durotomy during spine surgery. Can J Anaesth 49:100-102, 2002

12. Macfarlane MR, Symon L: Lyophilised dura mater: Experimental implantation and extended clinical neurosurgical use. J Neuro Neurosurg Psychiatry 42:854-858, 1979

13. Mayfield FH: Autologous fat transplants for the protection and repair of the spinal dura. Clin Neurosurg 27:349-361, 1980

14. Misra BK, Shaw JF: Extracerebral hematoma in association with dural substitute. Neurosurgery 21:399-400, 1987

15. Narotam PK, Reddy K, Fewer D, Qiao F, Nathoo N: Collagen matrix duraplasty for cranial and spinal surgery: A clinical and imaging study. J Neurosurg 106:45-51, 2007

16. Narotam PK, van Dellen JR, Bhoola KD: A clinicopathological study of collagen sponge as a dural graft in neurosurgery. J Neurosurg 82:406-412, 1995
17. Simpson D, Robson A: Recurrent subarachnoid bleeding in association with dural substitute. Report of three cases. J Neurosurg 60:408-409, 1984

18. Sin AH, Caldito G, Smith D, Rashidi M, Willis B, Nanda A: Predictive factors for dural tear and cerebrospinal fluid leakage in patients undergoing lumbar surgery. J Neurosurg Spine 5:224-227, 2006

19. Trevor PB, Martin RA, Saunders GK, Trotter EJ: Healing characteristics of free and pedicle fat grafts after dorsal laminectomy and durotomy in dogs. Vet Surg 20: 282-290, 1991

20. Trigo Cabral A, Lima $P$, Paiva E, Pinto A: A case of recurrent sciatica following a free adipose tissue graft. Rev Chir Orthop Reparatrice Appar Mot 75:412-414,1989

21. Urvoy P, Perlinski S, Berger M, Butin E, Mestdagh H: Cauda equina syndrome due to early postoperative migration of an adipose tissue flap following laminectomy. Acta Orthop Belg 56:513-516,1990 